\title{
INDEX TO VOLUME NO. II
}

(D) indicates a discussion of a paper at a meeting

Abramson, Arthur S. and Roussan, Matei S., 125

About the Neurological Sequelae of Herniated Intravertebral Disc, 22 I

Accidental Perforation of the Rectum, 3I4

A New Adaptor which obviates Problems associated with Condom External Urinary Drainage of Male Patients, 25

A New Programme of Sex Education \& Counselling for Spinal Cord Injured Adults and Health Care Professionals, I I I

Barrie, David, 99

Baud, C. A., see Rossier A. B., 36

Beck, J., see Weiss, Marian, I66

Bidart Y, and Maury M., I

Brown, Courtney W., see Odom, John A., 290

Burke, D. C., 268

Bussat, Ph., see Rossier, A. B., 36

Canzoneri III J., see Newsom M. J., 29

Cardiovascular collapse following Succinylcholine in a Paraplegic Patient, I99

Carle, Terry V., see Odom, John A., 290

Catecholamine Responses in Paraplegia, 238

Causes of Death in I I of 227 patients with traumatic spinal cord injury over a period of 9 years, 217

Cheshire, D. J. E., (D) 257, (D) 288

Chilgren, Richard, see Cole, Theodore, I I I

Cole, Theodore M., Chilgren, Richard and Rosenberg, Pearl, I I I

Comparative Catemnestic Studies of Two Groups of Paraplegics, 92

Congenital Absence of the Dens of Axis, 263

Cook, J. B., (D) 88, (D) 3I 8

Courvoisier, B., see Rossier, A. B., 36

Current Facts of Para-Osteo-Arthropathy (POA), 36

Denning, D., (D) I 77

Differential Diagnosis of Hip Contractures in Paraplegics and their Treatment, 86

Dollfus, P., (D) 320, $32 \mathrm{I}$ and Holderbach, G. L., Husser, J. M. Jacob-Chia, D., 306

Donath, A., see Rossier, A. B., 36

Downey, J. A., see Frewin, D. B., 238
Early Recognition of Heterotopic Calcifications by means of Alkaline Phosphatase, 79

El-Masri, W., see Walsh, J. J., 310

Engel, P. and Hildebrandt, G., I05

Evaluation of an Eye-movement controlled Wheelchair, 30

Experiences with Frog Breathing Tetraplegic Polio Victims as Telephone Operators, 253

Experimental Studies on the Value of Archery in Paraplegia, I59

Fincke, A. J., see Snow, J. C., 199

Francois, N., see Maury, M., 245

Frankel, H. L., 314, (D) 318, 320

Freehafer, Alvin A., 295

Frewin, D. B., Levitt, M., Myers, S. J. and Downey, J. A., 238

Fuhrer, M. J., see Newsom, M. J., 29

Gabbiani, G., see Rossier, A. B., 36

Gassler, R., 88

Greer, Wendy, see Harris, P., I 32

Griffiths, E. R., (D) 289, 293, (D) 277

Growth Problems in Cervical Injuries, 277

Guillaumat, M., see Maury, M., 245

Guttmann, Sir Ludwig and Mehra, N. C., I59, (D) 177, I78, (D) 252, (D) 257, (D) 289, (D) 293, (D) 319, 32 I

Hachen, H. J., see Rossier, A. B., 36

Hahn, Harry R., see Odom, John A., 290

Harris, P., (D) 32I, Patel, S. S., Greer Wendy \& Naughton, J. A. L., I32

Hildebrandt, G., see Engel, P., I05

Holderbach, G. L., see Dollfus, P., 306

Husser, J. M., see Dollfus, P., 306

Infante, F., see Rossier, A. B., 36

Intermittent Catheterisation with unsterile instruments, 179

Jackson, R. R., (D) 289, (D) 293, see Odom, John A., 290

Jacob-Chia, D., see Dollfus, P., 306

Jochheim, K. A. and Strohkendl, H., I73, see also Wahle, H., 92

Kerr, W. S., (D) 320

Knutssen, E., Lewnhaupt-Olsson, E., and Thorsen, M., 205 
Kripke, B. J., see Snow, J. C., 199

Lagier, R., see Rossier, A. B., 36

Levitt, M., see Frewin, D. B., 238

Lewnhaupt-Olsson, E., see Knutsson, E., 205

Long Term Spiroergometric Studies of Paraplegics during the Clinical Period of Rehabilitation, I05

McSweeney, T., (D) 89, (D) 285, (D) 293

Maury, M., Guillaumat, M., and Francois, N., 245, also see Bidart, Y., I

Maury, M., Francois, N. and Skoda, A., 22 I

Mehra, N. C., see Guttmann, Sir L., I 59

Meinecke, F. W., (D) 88, (D) 289, (D) 318, $32 \mathrm{I}$

Methods of Bracing in the Rehabilitation of the Paraplegic Child, I37

Michaelis, L. S., (D) 88, (D) 317

Muheim, D., see Rossier, A. B., 36

Must Appendicitis be still considered as a Rare Complication in Paraplegia?, 306

Myers, S. J., see Frewin, D. B., 238

Nakamura, Y., (D) I77, I95

Naughton, J. A. L., see Harris, P., 132

Nechtwatel, E., 79

Newsom, M. J., Conzoneri III J., Pelosof, H. V. and Fuhrer, M. J., 29

Non-Medical Management of Spinal Cord Injury, 96

Nuseibeh, I., see Walsh, J. J., 3 IO

Odom, John A., (D) 294, and Brown, Courtney, W., Jackson Robert R., Hahn, M. D., Carle, Terry V., 290

Our Experience of upper limb transfers in cases of tetraplegia, 245

Patel, S. S., see Harris, P., I32

Pearman, J. W. and Shah, S. K., 25

Pelosof, H. V., (D) 320, see Newsom, M. J., 29

Perforated Peptic Ulcer in Paraplegia, 310

Physical work capacity and physical conditioning in paraplegic patients, 205

Pool, G. M., (D) 257, and Weerden, G. J. v., 253

Pouezat, J. A., see Rossier, A. B., 36

Price, Mary, 217

Projecta Paraplegia, 90

Psychological and Social Reactions to Acute Spinal Paralysis, I32

Rezaian, S. M., 263

Rosenberg, Pearl, see Cole Theodore, M., I I I
Rossier, A. B., (D) 89, (D) 252, (D) 318, and Bussat, Ph., Infante, F., Zender, R., Courvoisier, B., Muheim, G., Donath, A., Vasey, H., Taillard, W., Lagier, R., Gabbiani, G., Baud, C. A., Pouezat, J. A., Very, J. M., Hachen, H. J., 36

Sessions, G. P., see Snow, J. C., 199

Scoliosis in Paraplegia, 290

Shah, S. K., see Pearman, J. W., 25

Siebens, A. A., (D) 293

Silva, J. Francis, I 46

Silver, J., (D) 320

Skoda, A., see Maury, M., 22 I

Snow, J. C., Kripke, B. J., Sessions, G. P., and Finck, A. J., 199

Some Experiences with non-traumatic paraplegia in Malaysia, I46

Sport as part of Therapy and Rehabilitation of Paraplegics, I66

Stoephasius, E., (D) 252

Stöger, M., (D) 252, see Zubrecky, G., 228

Strach, E. H., I 37

Strohkendl, H., see Jochheim, K. A., I73

Surgical Reconstruction of Prehensile Function in Tetraplegics, I44

Taillard, W., see Rossier, A. B., 36

Talbot, H., (D) 252, (D) 317

The Circulatory Behaviour in Complete Chronic Paraplegia, I

The Orthosis for restoration of prehensile function in tetraplegia, 228

The Role of Spinal Cord Facilitation in Neurogenic Bladder Function, I25

The Treatment of Myelomeningocele Patients with Paralytic Hip Deformities by Iliopsoas Transfer, 295

The Value of Particular Sports of the Wheelchair-Disabled in Maintaining Health of the Paraplegic, I73

Thomas, D., (D) 320

Thorsen, Marika, see Knutsson, E., 205

Traumatic Spinal Paralysis in Children, 268

Vasey, H., see Rossier, A. B., 36

Very, J. M., see Rossier, A. B., 36

Wahle, H. and Jochheim, K. A., 92

Walsh, J. J., (D) 89, (D) 319 and Nuseibeh, I., El-Masri, W., 3 IO

Weerden, G. J. v., see Pool G. M., 253

Weis, Marion and Beck, J., I66

Zubrecky, G., (D) 89, I44, I79 and Stöger, M., 228 